University of Nebraska - Lincoln

DigitalCommons@University of Nebraska - Lincoln

Faculty Publications from the Harold W. Manter Laboratory of Parasitology

$10-2005$

\title{
Three Rarely Reported Digeneans Inhabiting Amphibians from Vancouver Island, British Columbia, Canada
}

\author{
David Zamparo \\ University of Toronto \\ Daniel R. Brooks \\ University of Toronto,dnlbrooks@gmail.com
}

Follow this and additional works at: https://digitalcommons.unl.edu/parasitologyfacpubs

Part of the Parasitology Commons

Zamparo, David and Brooks, Daniel R., "Three Rarely Reported Digeneans Inhabiting Amphibians from Vancouver Island, British Columbia, Canada" (2005). Faculty Publications from the Harold W. Manter Laboratory of Parasitology. 223.

https://digitalcommons.unl.edu/parasitologyfacpubs/223

This Article is brought to you for free and open access by the Parasitology, Harold W. Manter Laboratory of at DigitalCommons@University of Nebraska - Lincoln. It has been accepted for inclusion in Faculty Publications from the Harold W. Manter Laboratory of Parasitology by an authorized administrator of DigitalCommons@University of Nebraska - Lincoln. 


\section{Three Rarely Reported Digeneans Inhabiting Amphibians From Vancouver Island, British Columbia, Canada}

David Zamparo and Daniel R. Brooks, Department of Zoology, University of Toronto, Toronto, Oritario M5S 3G5, Canada. e-mail: zamparo@zoo.utoronto.ca

ABSTRACT: Three rarely reported species of digeneans were collected in amphibian hosts from Diversion Reservoir, Sooke, Vancouver Island, British Columbia, Canada. The endangered anuran Rana aurora hosted Glypthelmins californiensis, Gorgoderina multilobata, and Megalodiscus microphagus. In addition, the anuran Pseudacris regilla and the caudatan Taricha granulosa hosted Megalodiscus microphagus. Gorgoderina multilobata has been reported only once since 1936 and has never been reported outside of California. We note several characters not previously reported for Gorgoderina multilobata and G. aurora.

During the summer of 2002, a single specimen of the red-legged frog, Rana aurora; 3 rough-skinned newts, Taricha granulosa; and 4 Pacific tree frogs, Pseudacris regilla; were collected from Diversion Reservoir, Sooke, Vancouver Island $\left(123^{\circ} 58^{\prime} 18.4^{\prime \prime} \mathrm{W} ; 48^{\circ} 30^{\prime} 0.54^{\prime \prime} \mathrm{N}\right)$ and examined for parasitic helminths. Digenetic trematodes were collected while alive and fixed by shaking in hot formalin, and then stored in $70 \%$ ethanol. Hosts were eutheninized with benzocaine. Specimens were stained with Mayer's haematoxylin, dehydrated, and mounted in Canada balsam for identification and deposited at the United States National Parasite Collection in Beltsville, Maryland (USNPC).

The anuran $R$. aurora hosted 2 specimens of Gylpthelmins californiensis (Cort, 1919) Miller, 1930, in the anteriormost part of the small intestine (USNPC 95033). Glythelmins californiensis was originally described in this host from a frog farm near San Francisco by Cort (1919). Ingles (1936) later reported it in Rana boyli from Butte County, California. Other reports of $G$. californiensis in $R$. aurora include western Washington and Oregon (Lehmann, 1960), Langley and Duncan, British Columbia (O'Grady, 1987); and Sooke and Nanaimo, British Columbia (Moravec, 1984). This species has also been reported from Mexico in Rana pipiens (Caballero y Caballero, 1942) (actually an undetermined member of the "Rana pipiens group" because Rana pipiens sensu stricto does not occur in Mexico); Rana dunni (Pulido-Flores, 1994; RazoMendivil et al., 1999; Perez-Ponce de Léon et al., 2000); $R$. megapoda (Razo-Mendivil et al., 1999); Rana montezumae (Caballero y Caballero, 1942; Leon-Regagnon, 1992; Razo-Mendivil et al., 1999; Perez-Ponce de Léon et al., 2000), and $R$. neovolcanica (Razo-Mendivil et al., 1999).

All 3 amphibian species from Diversion Reservoir hosted Megalodiscus microphagus Ingles, 1936 . The $R$. aurora specimen hosted $8 \mathrm{M}$. microphagus in the intestine (USNPC 95034), and 1 of the $4 P$. regilla was infected with 2 intestinal $M$. microphagus (USNPC 95035). Two of the 3 rough-skinned newts, $T$. granulosa, were infected with $M$. microphagus, 1 with a single specimen in the esophagus and the other with 7 in the esophagus (USNPC 95037) and 2 in the intestine (USNPC 95036). Ingles (1936) described $M$. microphagus in Bufo boreas from Shasta County, California, noting that immature specimens occurred in the intestine, rectum, and bladder with mature specimens, having lost eyespots, found only in the bladder. We, on the other hand, found immature specimens in the esophagus of $T$. granulosa and mature specimens only in the intestine of all 3 host species. This is an unusual find because all other species of Megalodiscus occur in the rectum.

Previous reports of $M$. microphagus in Rana aurora include Oregon (Macy, 1960), Nanaimo, Sooke, and Marion Lake, British Columbia (Efford and Tsumura, 1969; Moravec, 1984); and Endert's Beach, Crescent City, Del Norte County, California and Redwood National Park, Humboldt County, California (Goldberg et al., 2004). Megalodiscus microphagus has also been reported previously in Taricha granulosa and Pseudacris regilla from Oregon (Macy, 1960) and from Marion Lake, British Columbia (Efford and Tsumura, 1969), and in T. granulosa from Nanaimo and Sooke, British Columbia (Moravec, 1984). Other reported hosts include the brown and long-toed salamanders, Ambystoma gracile 
and A. macrodactylum, from Marion Lake, British Columbia (Efford and Tsumura, 1969); the Pacific giant salamander, Dicamptodon ensatus, from Oregon (McCauley and Pratt, 1959); the boreal toad, Bufo boreas, from Marion Lake, British Columbia (Efford and Tsumura, 1969); the foothill yellow-legged frog, Rana boylei, from Humboldt, California (Walker, 1965); and the western spotted frog, Rana pretiosa, from Bear Spring, Oregon (Panitz and Briggs, 1968).

Rosen and Manis (1976) reported M. microphagus in 1 of 70 bullfrogs, $R$. catesbeiana, from Arkansas. However, there is no record of these authors having deposited voucher specimens in any museum collection, so we are unable to confirm this identification. We believe this report might have been a misidentification. Rana catesbeiana has previously been reported as hosting $M$. temperatus (Stafford, 1905) Harwood, 1932 (e.g, Slagle, 1966; Brooks, 1977; Muzzall, 1991; Andrews et al., 1992; McAlpine and Burt, 1998) and M. intermedius (Hunter, 1930), Harwood, 1932 (e.g., Brandt, 1936), which might be a synonym of $M$. temperatus.

Two specimens of Gorgoderina multilobata Ingles and Langston, 1933 were found to infect the urinary bladder of the $R$. aurora specimen (USNPC 95032). Gorgoderina multilobata was originally reported in $R$. boyli from the Santa Cruz Mountains and streams near Chico, California and in $R$. aurora from a small pond near Berkeley, California. Ingles (1936) later described $G$. aurora from $R$. aurora, stating that specimens of $G$. aurora had been considered to be young ovigerous adults of $G$. multilobata, on the basis of smaller body size (5-8 $\mathrm{mm}$ vs. 7.1-11.7 $\mathrm{mm}$ ), and greater body width to body length ratio (1:8.4-12 vs. 1:3.8-8.5). Ingles (1936), however, noted that the small (G. aurora) and large ( $G$. multilobata) ovigerous forms could be differentiated consistently on the basis of the ratio of oral sucker length to ventral sucker length (1:2.0-2.4 vs. 1:1.69, respectively) and in the morphology of the vitellarium (irregularly lobed vitellarium vs. 2 clusters of 7-9 lobes, respectively). Ingles (1936) also reported G. multilobata in $R$. pretiosa (= R. cascadae, Turner, 1958), extending the range from the Santa Cruz Mountains north to the Oregon-California border. However, since the Ingles (1936) description, there has been no other report of $G$. aurora and there has been only one other report of $G$. multilobata, also from California (Walker, 1965).

In attempting to identify the material collected from Vancouver Island, we examined the holotype and 2 paratypes each of $G$. multilobata (USNPC 8665) and G. aurora (USNPC 8932). Ingles and Langston (1933:244) described the vitellarium of G. multilobata as "two grapelike clusters, each possessing from seven to nine lobes," and the vitellarium of G. aurora as "not having regularly lobed vitellaria" (Ingles, 1936:77). Examination of deposited material revealed that G. multilobata has 2 clusters of 8 lobes, whereas $G$. aurora specimens have 6 lobes on the sinistral cluster and 7 lobes on the dextral cluster. The specimens we collected from Sooke, Vancouver Island have 7 lobes in each cluster.

Ingles and Langston (1933) described a bipartite internal seminal vesicle (but did not mention or illustrate a pars prostatica) and esophagus surrounded by glands for $G$. multilobata. We confirm herein, that these structures are also present in G. aurora and the specimens from Sooke, Vancouver Island.

Ingles and Langston (1933) described G. multilobata as having ceca of unequal length, whereas Ingles (1936) reported that $G$. aurora has ceca of equal length. Our examination of type material indicates that the sinistral cecum is longer than the dextral in G. aurora, whereas in G. multilobata the dextral cecum is slightly longer than the sinistral. The specimens from Sooke, Vancouver Island resemble G. multilobata in having a shorter sinistral cecum and longer dextral cecum. Ingles and Langston (1933) described the ovary of G. multilobata as being on either side of the body. Our examination of type material indicates that the ovary is located on the sinistral side of the body in G. aurora and on the dextral side in G. multilobata. The specimens from Vancouver Island resemble $G$. aurora by having ovaries on the sinistral side of the body. Finally, our examination of the type material indicates that the uterus does not overlap the testes in $G$. multilobata but does so in $G$. aurora. In this regard, the specimens from Vancouver Island resemble G. multilobata. Finally, specimens collected in this report have an oral : ventral sucker width ratio less than 2 (1:1.79), resembling G. multilobata more than $G$. aurora.

There appear to be 2 possible interpretations of the morphological diversity encountered in the present study. One possibility is that both
G. multilobata and G. aurora are valid species, and the material from Vancouver Island represents a third species. The other possibility is that all material pertains to a single highly variable species, G. multilobata. Resolving this conundrum will require additional collections, both to provide substantial numbers of specimens for morphological analysis, and to provide material for molecular analysis to strengthen inferences about the significance of the morphological diversity encountered.

We would like to thank Ivan Zubovic for assistance in the field and Kelly Sendall, Collection Manager, Invertebrates, Fish and Herpetology of the Royal British Columbia Museum for housing the Rana aurora specimen (RBCM 1946). This study was funded by a research grant from the Natural Sciences and Engineering Research Council (NSERC) of Canada to Daniel R Brooks F.R.S.C., and conducted under the Ministry of Water, Land, and Air Protection permit D009957.

\section{LITERATURE CITED}

Andrews, K., R. Lampley, M. Gillman, D. Corey, S. Ballard, M. BLASCZYK, AND W. DYER. 1992. Helminths of Rana catesbeiana in Southern Illinois with a checklist of helminths in bullfrogs of North America. Transactions of the Illinois State Academy of Science 85: 147-172.

Brandt, B. B. 1936. Parasites of certain North Carolina Salientia. Ecological Monographs 6: 491-532.

BrooKs, D. R. 1977. Platyhelminths of amphibians in Nebraska. Bulletin of the University of Nebraska State Museum 10: 65-92.

CABAllero y Caballero, E. 1942. Trematodos de las ranas de la cienaga de Lerma, estado de Mexico. III. Redescripcion de una forma norteamerica de Haematoloechus y algunas consideraciones sobre Glypthelmins californiensis (Cort, 1919). Anales del Instituto Biologia, Universidad Nacional de Mexico 13: 635-640.

CORT, W. W. 1919. A new distome from Rana aurora. University of California Publications in Zoology 19: 283-289.

EFFORD, I., AND K. TSUMURA. 1969. Observations on the biology of the trematode Megalodiscus microphagus in amphibians from Marion Lake, British Columbia. American Midland Naturalist 82: 197-203.

GoldBerG, S. R., C. R. Bursey, N. Nieto, AND J. Bettaso. 2004. Rana aurora aurora (Northern red-legged frog). Endoparasites. Herpetological Review 35: 161-162.

INGLES, I. G. 1936. Worm parasites of California amphibia. Transactions of the American Microscopical Society 55: 73-92.

, AND C. I. LANGSTON. 1933. A new species of bladder fluke from California frogs. Transactions of the American Microscopical Society 52: 243-245.

LEHMANN, D. L. 1960. Some parasites of central California amphibians. Journal of Parasitology 46: 10.

LEON-REGAGNON, V. 1992. Fauna helmintologica de algunos vertebrados acuaticos de la cienaga de Lerma, Mexico. Anales del Instituto Biologia, Universidad Nacional de Mexico 63: 151-153.

MACY, R. 1960. On the life cycle of Megalodiscus microphagus Ingles (Trematoda: Paramphistomatidae). Journal of Parasitology 46: 662.

MCAlPINE, D., AND M. BURT. 1998. Helminths of bullfrogs, Rana catesbeiana, green frogs, $R$. clamitans, and leopard frogs, $R$. pipiens in New Brunswick. Canadian Field Naturalist 112: 50-68.

MCCAuley, J., AND I. PRATT. 1959. The paramphistome Megalodiscus microphagus Ingles, 1936, from the giant salamander Dicamptodon ensatus (Eschscholtz, 1833) from Oregon. Journal of Parasitology 45: 614 .

MORAVEC, F. 1984. Some helminth parasites from amphibians of Vancouver Island, B. C., western Canada. Vestnik Ceskoslovenske Spolencnosti Zoologicke 48: 107-114.

Muzzall, P. 1991. Helminth infracommunities of the frogs Rana cates beiana and Rana clamitans from Turkey Marsh, Michigan. Journal of Parasitology 77: 366-371.

O'GRADY, R. T. 1987. Phylogenetic systematics and the evolutionary history of some intestinal flatworm parasites (Trematoda: Digenea: Plagiorchioidea) of anurans. Ph.D. Thesis. University of British Columbia, Vancouver, British Columbia, Canada, 327 p.

PANITZ, E., AND J. BRIGgS. 1968. Rana cascadae, new definitive host of Megalodiscus microphagus Ingles, 1936 (Trematoda: Paramphistomatidae) in Oregon. Bulletin of Wildlife Diseases 4: 21.

Perez-Ponce de Léon, G., V. Leon-Regagnon, L. Garcia-Prieto, and U. RAzO-MENDIVIL. 2000. Digenean fauna of amphibians from Cen- 
tral Mexico: nearctic and neotropical influences. Comparative Parasitology 67: 92-106.

Pulido-Flores, G. 1994. Helmintos de Rana dunni especie endemica del lago de Patzcuardo, Michoacan, Mexico. Anales del Instituto Biologia, Universidad Nacional de Mexico 65: 205-207.

Razo-Mendivil, U., J. P. Laclette, and G. Perez-Ponce de Léon. 1999. New host and locality records for three species of Glypthelmins (Digenea: Macroderoididae) in anurans of Mexico. Journal of the Helminthological Society of Washington 66: 197-201.
Rosen, R., AND R. MANIS. 1976. Trematodes of Arkansas amphibians. Journal of Parasitology 62: 833-834.

SLAGLE, W. 1966. A survey of the helminths in Rana catesbeiana Shaw and Rana pipiens Schreber from Brazos County, Texas, and vicinity. M.Sc. Thesis. Texas A\&M University, College Station, Texas, $45 \mathrm{p}$.

WALKER, M. E. 1965. A survey of the helminth parasites of Rana boylei from Humboldt County, California. M. Sc. Thesis. Humboldt State University, California, $32 \mathrm{p}$. 